\title{
In memoriam of Jean-Claude Rage
}

\author{
Zbyněk Roček $^{1}$ (i) - Marc Louis Augé ${ }^{2} \cdot$ James D. Gardner ${ }^{3}$
}

Received: 1 July 2018 / Accepted: 19 July 2018 / Published online: 9 August 2018

(C) Senckenberg Gesellschaft für Naturforschung and Springer-Verlag GmbH Germany, part of Springer Nature 2018

The palaeontological community suffered a great loss when the prominent French researcher Jean-Claude Rage, Emeritus Research Director (Directeur de recherche émérite) in the Centre de recherche sur la paléobiodiversité et les paléoenvironments at the Muséum National d'Histoire Naturelle, Paris, unexpectedly died of a heart attack on 30 March 2018 in Paris. Jean-Claude Rage was a palaeoherpetologist whose research career spanned more than five decades (see the earlier biographical sketch and career summary by Steyer and Buffetaut [2012] on the occasion of Jean-Claude's 70th birthday). Jean-Claude excelled at the challenging task of identifying fossil amphibians and squamates from their isolated and often fragmentary, small-sized bones. Such identifications require both a comprehensive knowledge of the numerous and often subtle osteological features that differentiate taxa from each other, coupled with an appreciation for how the diagnostic utility of those features may be confounded by various kinds of intraspecific variation (e.g. individual, ontogenetic, sexual, and temporal). Additionally, Jean-Claude was a renowned specialist in fossil snakes. The identification of fossil snake taxa is especially challenging, because their record is biased towards vertebrae and those bones, which may number in hundreds for a single individual, differ according to their placement along the vertebral column. For those reasons, it is even more challenging

\section{Zbyněk Roček}

rocek@gli.cas.cz

Marc Louis Augé

marc.louis.ed.auge@gmail.com

James D. Gardner

james.gardner@gov.ab.ca

1 Department of Palaeobiology, Institute of Geology, Czech Academy of Sciences, Rozvojová 135, 16500 Prague 6, Czech Republic

2 Muséum national d'Histoire naturelle, Département Histoire de la Terre, UMR 20, CNRS, rue Buffon, 75231 Paris, France

3 Royal Tyrrell Museum of Palaeontology, Box 7500, Drumheller, AB T0J 0Y0, Canada to determine whether observed differences between isolated fossil snake vertebrae indicate those bones belong to different species or, instead, are from different positions along the column in a single species or even a single individual. Early in his career, Jean-Claude recognised that the abundant amphibian and squamate bones preserved in the Mesozoic and Cenozoic fossil record not only were taxonomically identifiable but also were informative for stratigraphic correlations and insights into phylogeny, palaeobiogeography, palaeoecology, and taphonomy. Jean-Claude was equally comfortable pursuing solo-authored projects as he was collaborating with colleagues. Thanks to his palaeoherpetological expertise, professionalism, and collegial disposition, Jean-Claude routinely was invited by colleagues to collaborate with them, especially to help identify, describe, and interpret amphibian and squamate fossils found during their fieldwork and museum visits.

Jean-Claude Rage was born on 1 March 1943 in Lyon, France, where his father owned a large food shop and his mother was a housewife. Jean-Claude was the youngest of three children (he had two sisters, but the younger died before he was born). His parents taught him to read before entering primary school and were very proud of him. Following the untimely death of his father, when JeanClaude was only 10 years old, the family moved to Boënsur-Lignon in the Département de la Loire, about $80 \mathrm{~km}$ west of Lyon. There, Jean-Claude was exposed to a more rural setting and his enduring love of nature can be traced to that interval. Later, the family moved again within the Département de la Loire, this time to Saint Chamond near Saint Étienne. Jean-Claude attended secondary school (collège) in Saint Étienne and graduated from there with his school-leaving (baccalaureate) certificate.

At the age of 20, in 1963, Jean-Claude returned to his birth city, where he entered the Faculté des Sciences in Lyon and studied palaeontology in the Département des Sciences de la Terre. His master's thesis (Thèse de $3^{\mathrm{e}}$ cycle), prepared under the guidance of the geologist Prof. Louis David, was entitled "Contribution à l'étude des anoures quaternaires" and was successfully defended in 1968. Jean-Claude's first published paper, which documented amphibian and reptile bones 
recovered from a pre-Neanderthal cave occupation site in Southeastern France (Rage 1969), demonstrated his talent for identifying amphibians and squamates on the basis of isolated bones. Wanting a better appreciation for how ontogenetic change can effect skeletal features, around this time JeanClaude approached Michel Delsol, who was a professor of biology at the Catholic University in Lyon and a specialist in postembryonic development of amphibians. For the remainder of his career, Jean-Claude remained in close contact with Prof. Delsol, as one of us (ZR) recalls from their meeting in Lyon in April 1992. Jean-Claude's career-defining interest in snakes also manifested itself around this time, when he coauthored a paper (Rage and Truc 1970) reporting a range extension for the extant colubrid Elaphe scalaris (now Rhinechis scalaris) in Provence. That their paper resulted from chance discoveries during a recreational outing - rather than Jean-Claude's university studies - reflected his willingness to embrace all opportunities and avenues of enquiry. Although Jean-Claude's first snake paper lacked the osteological focus typical for many of his subsequent snake papers, its biogeographical component was to become a recurrent theme throughout his career, especially in the context of explaining past distributions through geological time.

Upon graduating in 1968 from the University of Lyon, Jean-Claude secured a position as adjunct researcher (Attaché de recherche) in the Centre National de la Recherche Scientifique (CNRS), based at the Faculté des Sciences in Lyon. Recognising Jean-Claude's early promise as a palaeontologist and, especially, his interest in snakes, his former supervisor Prof. David introduced Jean-Claude to Prof. Robert Hoffstetter. At that time, Hoffstetter was the Director of Research (Directeur de recherche) of CNRS based at the Université Pierre et Marie Curie Paris 6 and one of world's leading authorities on fossil snakes. Jean-Claude worked with Hoffstetter for about a decade, until the latter's retirement in 1979. Under Prof. Hoffstetter's supervision, Jean-Claude completed his $\mathrm{PhD}$ dissertation (Doctorat d'Etat), entitled "Paléontologie, phylogénie et paléobiogéographie des serpents" (Fig. 1). After successfully defending his dissertation in 1976, Jean-Claude became a researcher (Chargé de recherche) in CNRS based at the University Paris 6. He stayed there until 1997, when he moved to the Muséum National d'Histoire Naturelle, not far from the University. JeanClaude retired in 2008, but continued his research - and relished no longer having to attend meetings and deal with other tedious administrative tasks - as Emeritus Research Director (Directeur de research émérite) in the Centre de recherche sur la paléobiodiversité et les paléoenvironments. During the course of his lengthy career, Jean-Claude published 226 original scientific articles, three books, and 29 chapters in books (ResearchGate, accessed 20 June 2018); that is not a final count, because several additional papers are still in press. For a more detailed summary of Jean-Claude's

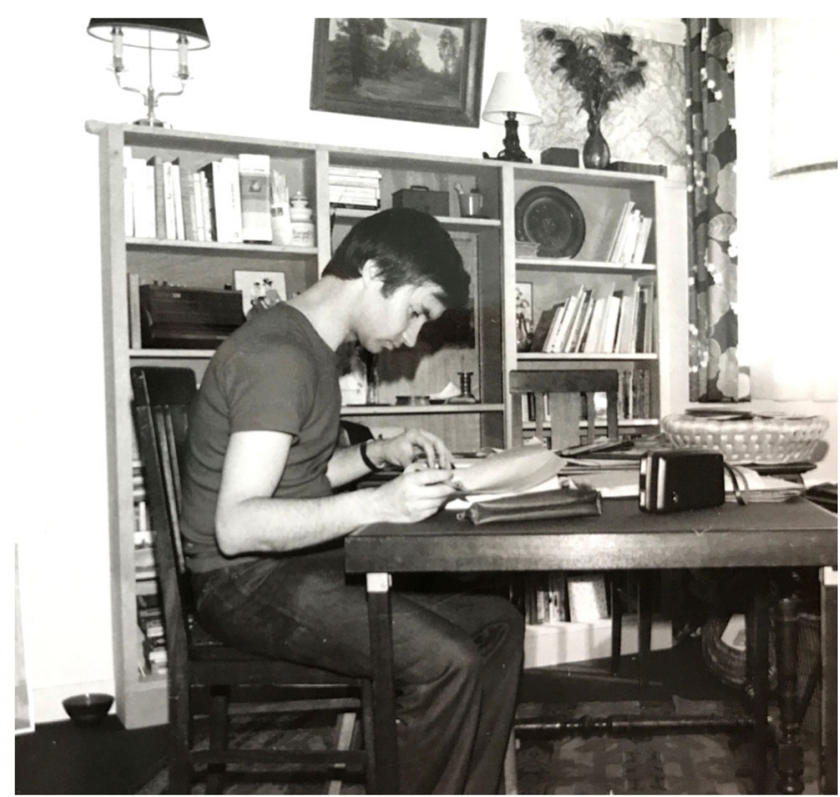

Fig. 1 Jean-Claude Rage writing his $\mathrm{PhD}$ thesis at home, 1 day before the birth of his daughter (1975)

research interests and contributions, see the biographical sketch by Steyer and Buffetaut (2012).

Jean-Claude's fruitful scientific career was balanced by an equally rich and satisfying personal life, which was grounded in his decades-long marriage to the fossil mollusc researcher Agnès Lauriat-Rage, now an emeritus professor from the Muséum National d'Histoire Naturelle. Upon moving from Lyon to Paris in 1968, Jean-Claude plunged into the student community, where he easily made many friends. In 1974, when he met Agnès Lauriat, a student of palaeontology who was preparing her thesis on fossil molluscs, he offered his services as an illustrator. That gesture lead to romance, followed by their marriage on 5 February 1975. Later that year, their daughter Estelle was born.

As alluded to above, Jean-Claude was an accomplished scientific illustrator whose informative drawings were immediately recognisable and complemented his detailed descriptive text. For Jean-Claude, the act of drawing specimens was an integral part of his study process, because accurately drawing a specimen helped him better recognise and understand its anatomical details. The time spent drawing specimens also provided ample opportunities for him to ponder other relevant subjects about each specimen, such as functional anatomy, variation, and adaptation. As a consequence, Jean-Claude achieved a deep appreciation for each of his illustrated specimens, beyond just a list of its anatomical features.

Jean-Claude's extensive, first-hand knowledge of fossils was appreciated by his colleagues, but could be a bit unnerving to students. When a student came to his office, for instance because they were interested in having him to supervise their thesis, without any formalities Jean-Claude would usher the student over to his drawers full of fossil 
bones. Palaeontologists often complain of scarcity of material, but here was the opposite situation - drawers full of tiny fossil bones, some complete and many fragmentary, obtained in great quantities thanks to hand quarrying, screen washing, and surface collecting. Jean-Claude would invite the student to select a specimen and briefly examine it, and then tell him what they knew about it. Jean-Claude would encouragingly reply, "Yes, you are well qualified to describe fossils." He then asked the student for their taxonomic identification of the fossil. If, after hearing their answer, Jean-Claude gently replied, "That's according to you" (Ça c'est toi qui le dit), the student understood that their identification was incorrect. Jean-Claude's extensive knowledge and helpful attitude were much appreciated by several generations of researchers. Many of us canvased his opinions on puzzling specimens and benefited from his constructive and supportive reviews of our manuscripts. Jean-Claude was often asked to write reviews of manuscripts submitted to various journals (including Palaebiodiversity and Palaeoenvironments) and he never declined, even if it meant taking time away from his own scientific work.

Jean-Claude was not devoted exclusively to his profession. Outside of work and family, he had broad and deep interests in various subjects, such as Roman art and old architecture. JeanClaude also liked to take photographs. He compiled several albums full of carefully described photographs of Roman churches, including close-ups of their architectural details, sometimes even with descriptions of how to get there on foot, because he and Agnès enjoyed walking excursions. He believed in the importance of family and had great love for his two granddaughters.

Another aspect of Jean-Claude's personal life that warrants mention, because it was to have implications for his career, was his love of sports. During his university studies in Lyon, he was a very good player of basketball. Probably as a result of some injury, in subsequent years he gradually began losing his ability to hear. Initially, his impaired hearing was not a significant impediment. For example, at the Third World Congress of Herpetology, held in Prague in 1997, he was able to give a plenary lecture entitled "Phylogeny and origin of snakes" to a packed auditorium and chat with colleagues. As his hearing deteriorated further, Jean-Claude discovered an unexpected benefit: without being distracted by noise and colleagues at the museum, he was able to concentrate more fully on his studies. Despite no longer being able to hear clearly, he remained actively engaged with colleagues and their research by reviewing their manuscripts and corresponding with them via email.

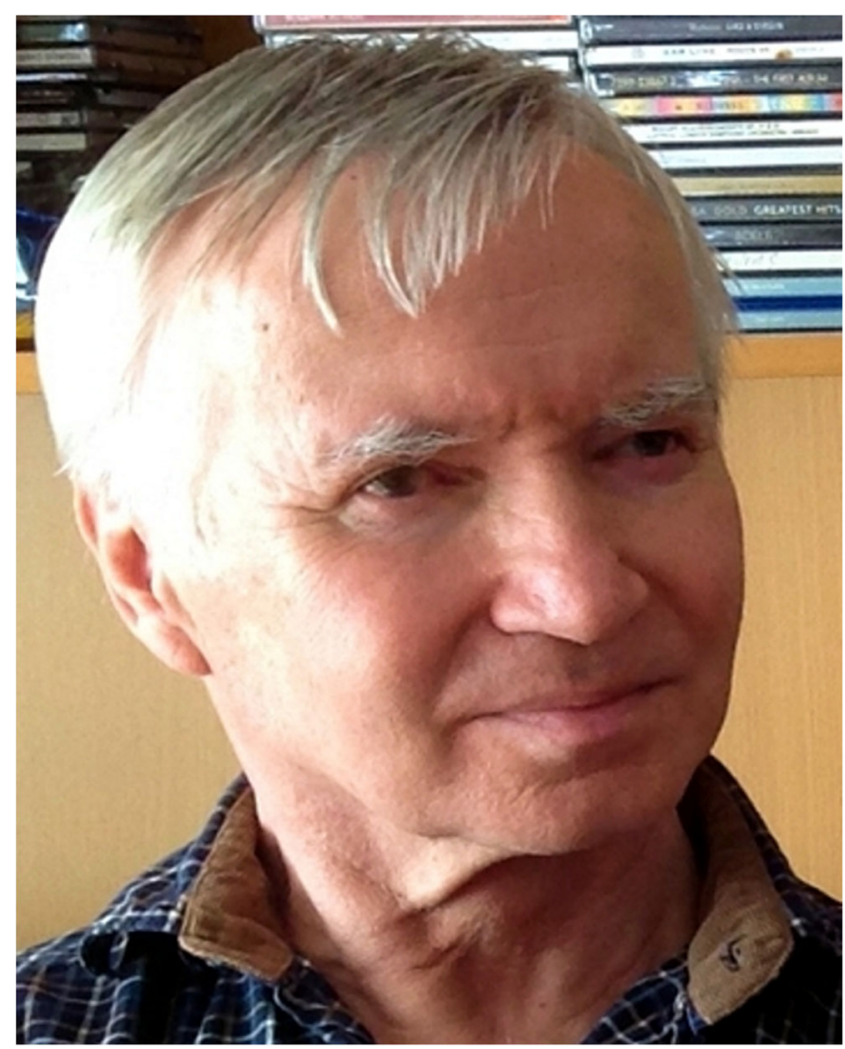

Fig. 2 Jean-Claude Rage at the age of 72 (2015)

Jean-Claude is buried south of Paris, in Orsay, where his wife came from and where they lived together in the late 1970s. As is typical for the death of a valued colleague, any attempt to summarize their life and contributions with a biographical account, list of published papers (too long to be printed here), and remembrances from colleagues, all seems pitifully inadequate. The death of Jean-Claude Rage leaves a gap in our ranks that will never be filled. We shall miss our colleague, mentor, and friend (Fig. 2).

\section{References}

Rage, J.-C. (1969). Les Amphibiens et les Reptiles découverts sur le sol de la cabane acheuléenne du Lazaret. Mémoires de la Société Préhistorique Française, 7, 107-110.

Rage, J.-C., \& Truc, G. (1970). Elaphe scalaris (la couleuvre à échelons): son extension en Provence. Bulletin Mensuel de la Société Linnéenne de Lyon, 6, 206-209.

Steyer, J.-S., \& Buffetaut, E. (2012). Dr. Jean-Claude Rage - an appreciation. Bulletin de la Société Géologique de France, 6, 491-493. 